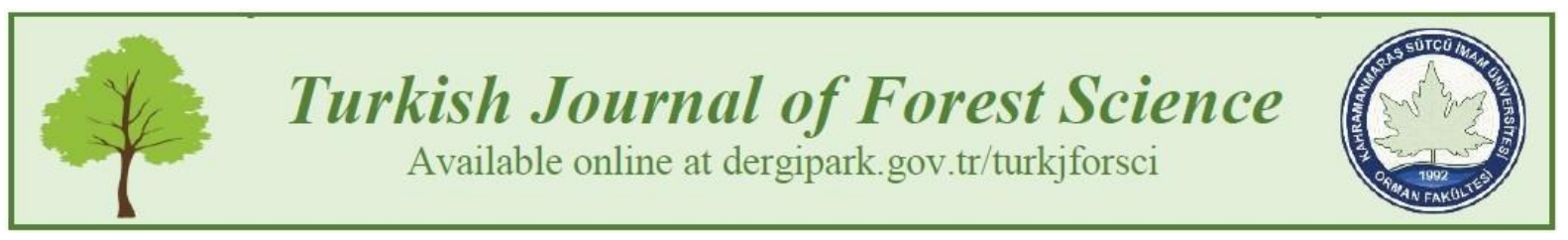

\title{
TRADITIONAL COURTYARD USAGE IN TURKS
}

\author{
Mahire ÖZÇALIK ${ }^{1}$ \\ ${ }^{1}$ Department of Landscape Architecture, Kirikkale University, Kirikkale \\ *Corresponding author: mahira.me@gmail.com
}

Mahire ÖZÇALIK: https://orcid.org/0000-0002-6420-4358

Please cite this article as: Ozcalik, M. (2021) Traditional courtyard usage in Turks, Turkish Journal of Forest Science, 5(2), 296-309.

\section{ESER BILGISI / ARTICLE INFO}

Araştırma Makalesi / Research Article

Geliş 7 Ocak 2021 / Received 7 January 2021

Düzeltmelerin gelişi 21 Haziran 2021 / Received in revised form 21 June 2021

Kabul 28 Haziran 2021 / Accepted 28 June 2021

Yayımlanma 31 Ekim 2021 / Published online 31 October 2021

\begin{abstract}
Since the beginning of the history of humanity, courtyards have been taking place on the stage of history as the areas needed by societies. Human beings, who are in constant relationship with the environment they live in during the historical process, have shaped the nature in accordance with their own wishes since the day they existed. This situation developed in the form of protection and struggle previously, and later became a continuous and organic with the discovery of the need for housing. This situation has caused the person to impose new meanings on the outer space. In this study, it is aimed to determine the courtyard, concept, history, characteristics and natural factors affecting the formation of traditional Turkish houses, to evaluate them as living spaces in traditional cultures and to reveal the potentials of courtyards.
\end{abstract}

Anahtar kelimeler: Courtyard, traditional Turkish house, courtyard use, courtyard types

\section{TÜRKLERDE GELENEKSEL AVLU KULLANIMI}

ÖZET: Avlular insanlık tarihinin başlangıcından beri toplumların ihtiyaç duyduğu alanlar olarak tarih sahnesinde yerini almaktadır. Tarihi süreç içinde yaşadığ çevre ile sürekli ilişki halinde olan insanoğlu, var olduğu günden itibaren doğayı kendi istekleri doğrultusunda biçimlendirmiştir. Bu durum önceleri korunma ve mücadele şeklinde gelişip, daha sonraları barınma ihtiyacının keşfedilmesi ile sürekli ve organik bir hale gelmiştir. Bu durum ise insanın dış mekana yeni anlamlar yüklemesine sebep olmuştur. Bu çalışmada geleneksel Türk evlerinin avlu kavramı, tarihçesi, özellikleri ve oluşumlarını etkileyen doğal ve kültürel faktörlerin belirlenmesi, geleneksel kültürlerde yaşam alanı olarak değerlendirilmesi ve avluların potansiyellerinin ortaya çıkarılması amaçlanmaktadır.

Anahtar Kelimeler: Avlu, geleneksel Türk evi, avlu kullanımı, avlu tipleri 


\section{INTRODUCTION}

Organizing and arranging the environment of mankind starts with the prehistoric period. In this period, firstly, caves were used for housing purposes and housing and open spaces were started to be created with the increase in construction and production activities. Cities have started to form as a result of differentiating and developing structures depending on socioeconomic structure. Over time, in Anatolia, which has hosted many civilizations, traditional houses have been formed according to topography, climate, socio-cultural and socioeconomic structure. The characteristics of these dwellings consist of buildings where housing needs are met and open spaces. With this cultural heritage a cultural mosaic with unique characteristics including the life and traditions of Anatolia for thousands of years has been formed (Bozkurt ve Altınçekiç, 2013).

The courtyards according to their characteristics are an architectural element called various types such as the outer courtyard, porch courtyard, fountain courtyard. The word "aule", which is originally Greek, was called as "sahn" in the early Islamic and Egyptian Mamlûk architecture before the use of the word courtyard, and the word "harim" was used in Ottoman architecture. Courtyards; It has become an indispensable element of Islamic and Turkish architecture with its pools, fountains, shaded porticoes in the middle as a source of coolness (Cantay, 1991).

One of the main defining features of the traditional Turkish house is that they are located in courtyards. The courtyard, which is usually located in front of the house, has become the most important living area of the house due to its traditional lifestyle. Because of this feature, traditional rural settlement is the determining factor in shaping the landscape. The courtyards of the traditional Turkish house have some common features. However, it may also vary from one place to another depending on local cultural differences. This change in courtyards is mainly due to differences in the livelihood economy. However, the spread of popular culture in today's era of globalization has given depth to spatial differentiation in the courtyard layout. The rapid spread of popular culture to rural areas has been caused by the tools of rapid communication and transportation. Especially in areas close to cities which are the starting center of the formation of popular culture, elements of traditional culture (hence the traditional courtyard) began to deteriorate, change, and even disappear (Köse, 2007). With the preservation of this cultural heritage with all its original qualities, the realization of life in current use as well as sustainability and creation of courtyard houses with these qualities will contribute to the transfer of national awareness to future generations (Bozkurt ve Altınçekiç, 2013).

The courtyard has been widely accepted as a typology addressing human needs by the architectural cultures developing in the continents around the world. From Moroccan organic morphology developed over time, mass production units in Daegu, The "Feng Shui" concept courtyards in Korea, Egyptian Hasan Conquest's designs applied in Mexico, historic Mesopotamian residences, to Post-colonial trials in Casablanca, courtyard; has become one of the global documents of human history for five thousand years without being limited to a certain geography, climate or culture. Islamic architectural culture has undoubtedly the richest examples of the courtyard. In the 20th century, the examples of the courtyard in the Islamic world have been examined by many architects and researchers, it can be said that the North African, Andalusian and Near Eastern cultures were in the foreground and Ottoman examples were found in these researches, but Seljuk architecture did not get the deserved attention and 
value in the courtyard literature. The presentation of the Masjid al-Nabawi (Figure 1) as the first courtyard example of Islamic architecture and the ignorance of the history of the courtyard in the Middle East results in an architectural identity separated from its integrity and the isolation of its interaction with different civilizations (Şimşek, 2015).

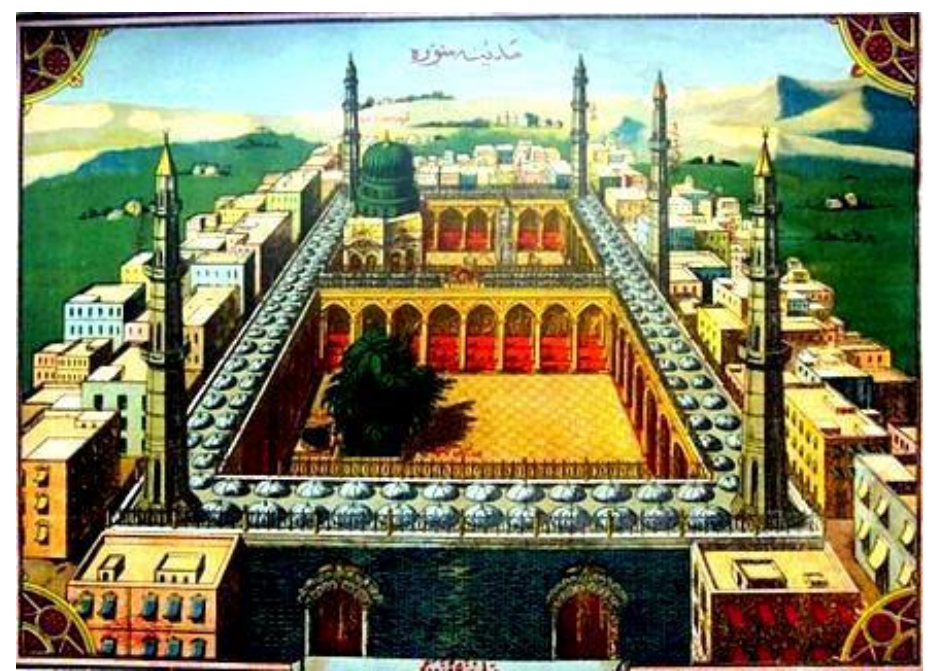

Figure 1. Masjid al-Nabawi (http://www.wikiwand.com/tr/Mescid-i_Nebev\%C3\%AE)

In this study, the place and importance of the courtyard in the life of Turkish history from nomadic life to settled life and even to the present day are mentioned, the affecting cultures and priorities have been examined through various sources having guidance features. The reason why the courtyard usage of Turks was examined In this study, to show the interact with nature in their history and even carry them into their homes, how the use of the courtyard has been shaped in time with the influence of the design concepts influenced by the understanding of nature, how traditional values are integrated with the importance they attach to aesthetics. As a result of this study, it is aimed to put forward a more detailed perspective for future urban or rural life planning, to emphasize that the value of courtyard should not be lost in Turkish culture and to create an illuminating archive document with this article.

\section{MATERIAL AND METHODS}

The main materials of the research are the courtyard usage and characteristics of the Turks' culture from the past to the present. In the compilation of the data on the subject of the article and the realization of the method related stages, the examination of the domestic and foreign previous studies on the subject has an important place. Some data has been obtained by making detailed literature searches on the subject of the article, which is determined as "Traditional Courtyard Use in Turks". In the research findings section, the results of the literature surveys are presented as outlined general subject headings.

A three-step study is conducted on the contents of the topic titled as "Traditional Courtyard Use in Turks" These stages are literature searching, carefully identifying and using the data to be used in general terms and evaluating all written and visual data deemed appropriate. In this study, which is performed with the three-stage method followed, the below results is reached. 
- Within the scope of literature research; Turkish house and courtyard concepts, historical development of courtyards, courtyard characteristics and natural and cultural factors affecting courtyard formations are examined.

- The outline of the article structure is created with carefully compilation of data sources such as theses, articles, journals and major internet sites on courtyard usage from past to present for the subject and the topics determined about this study.

- Specified data and photographs are presented in accordance with the study and with their bibliographies.

\section{RESULTS AND DISCUSTION}

\section{Concept of Courtyard in Traditional Turkish Houses}

The courtyard is usually in the middle of the buildings. It is a wide section of the buildings and optionally its upper part open to sky or sheltered. Also called atrium in architecture. Its upper part is generally left open to sky in Turkish architecture (Anonymous-a).

The courtyard or patio, which is the open space of the house, is generally the semi-general part. However, this may vary according to the differences in the social relations, privacy and sovereignty of cultures. For example, a traditional Chinese house develops around an enclosed inner courtyard; there is a desire to ensure family control, not privacy ( $\mathrm{Xu}$, 1998:279-280).

According to Arseven (1975), "avula" is synonymous with the courtyard, which is the name given to open spaces in front of the old Greek houses. This place, which was called as courtyard in Homer period, refers to the open section within the houses. Each house in that period had two courtyards in this way. There were rooms allotted for men around one of them and the around of the other had rooms for women. This practice is also present in Roman houses and one of these courtyards is called "atrium", and the other is called "peristhylium". In addition to these, terms and definitions such as inner courtyard, outer courtyard, front courtyard, inn courtyard, portico courtyard, ceremonial courtyard, covered courtyard, farm courtyard have emerged according to their position or function. If we explain these definitions; The inner courtyard is the courtyard located in the middle or inner part of the structure. The courtyards, which form part of the structure in large mosques and are integral part of it, are called inner courtyards or "harem". The outer courtyard of the mosque is the large square within the boundary surrounding the building. This is called "harim". The front courtyard is the courtyard in front of the buildings. Inn courtyard; these are the big squares where vehicles are placed and the goods are loaded and unloaded in buildings such as the old inn and caravanserai. Portico courtyard; are semi-open buildings surrounded by porticoes.

Ceremony courtyard; some official buildings and building complexes are defined as courtyards reserved for ceremonies; also called the courtyard of honor.

Farm yard; It is defined as a large courtyard and square located in the middle of poultry houses and stables of the farms. 


\section{Another term related to the courtyard is the garden courtyard. In the middle of the garden with lawn and flower beds are arranged in the form of courtyards (M.Larousse, 1990:886).Courtyard in Islamic Architecture}

The special features of the Umayyad and Abbasid mosques, which are two important civilizations in Islamic architecture, are square and transverse rectangular courtyards. Square courtyard was appeared for the first time as the Masjid al-Nabawi (Figure 2), which was reconstructed at the beginning of the VIII. century in the area where Prophet Muhammet's house is located. This was brought to life with real values in Raqqa Grand Mosque (772) and Ibn Tolun Mosque in Cairo (879). Transverse rectangular courtyard are seen in the design preferences of the Damascus Umayyad Mosque (715), Harran Ulu Mosque (744-750), Kufe Mosque (second half of the 7th century), Baghdad Masjid al-Kebir (809) and Cairo Hakim Mosque (early XI century). During this period, courtyards are located at the entrance of many mosques and buildings and are surrounded by prayer areas of different depths. Qasr al-Tuba (744) stands out as a large building with a double square courtyard. Qasr al-Hayr al-Gharbi and Khirbat Al-Mafjar Palace which belonged to the second quarter of the VIII. century, were the important palace structures of the Umayyad period with their square porch courtyards. The porticoes with column were built with L sectioned legs at the corners. In the Damascus Umayyad Mosque, the octagonal treasury building (Beytulmal) rising above the reused columns and heads and the courtyard with the fountain and second treasury building, which were later constructed, were evaluated. In the 12th century, Ibn Jubayr explained that the courtyard of the Damascus Umayyad Mosque with its lively, vibrant appearance was the meeting place of the people and that people wandered from one end to the other in this place, which was lit with many candles at night (Cantay, 1991).

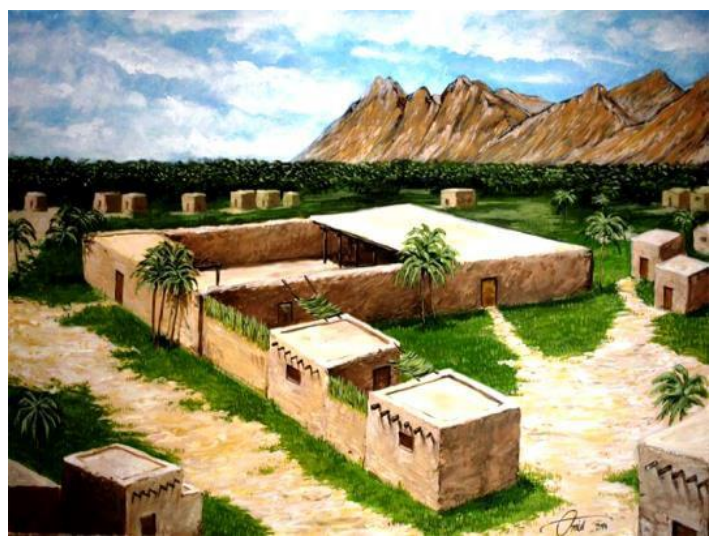

Figure 2. The first appearance of the Masjid al-Nabawi where the square courtyard was first seen- Medina / Saudi Arabia (https://tr.redsearch.org/images/5132455\#images-8)

\section{Courtyards in Turkish Architecture Before Anatolia}

The four-iwan courtyard type houses of the 9th and 13th centuries, uncovered in Tirmiz, Merv and Samian, are the first examples of an architectural tradition that will always be present. The Tirmiz Palace of the Karakhanes (11-12th century) attracts attention due to the establishment of a four-iwan courtyard as well as the opening of the large throne iwan to the courtyard with the arched portico in front of it. The Leşker-i Bazar Palace (beginning of the 11th century) and the 3rd Mesud Palace (beginning of the 12th century) near the bust are the Ghaznavian palaces built in the four-iwan courtyard type. The Merv Palace of the Great 
Seljuks (11-12th century) was built in the same style. Başane Mosque of the 11-12th centuries of Karakhanes with a large rectangular courtyard and a large iwan in the direction of Qibla, Dehistan Grand Mosque with the courtyard iwan dome layout are important. Zeware Ulu Mosque (1135) and İsfahan Ulu Mosque (11th century), one of the great Seljuk mosques were built on the basis of a four-iwan courtyard and the courtyard-iwan-dome establishment was seen in the its direction of qibla. From these structures, Isfahan Ulu Mosque (Figure 3) is the most important Great Seljuk monument with its large courtyard and large scale plan. Rey and Hargird madrasahs of the Great Seljuks (end of the 11th century) also have courtyards with four iwans. The Great Seljuk, Gazneli and Karahanlı ribats are caravanserai buildings generally built in courtyard style with four iwans. Akçakale (end of the 11th century) On the way to Mary-Amül is a caravanserai with two square courtyards on the building axis and in both courtyards, four-iwan courtyard type with portico was successfully applied. In the first courtyard of Ribat-1 Sharif on the Nişabur-Merv road, the system was repeated with a rectangular plan. The madrasahs built by Zengi in Aleppo and Damascus in the 12th century have different numbers of iwans opening to the courtyard. A large pool in the middle of the courtyard and the opening of the mosque to the courtyard with three arches can be shown as the main feature of these madrasah structures. The waters reaching the large pool in the courtyard through the water lane from the iwan with selsebil in Damascus Nuriyye Madrasah are seen as the first examples of a design that uses courtyard architecture. Basra Gumustekin Madrasah is a structure that leads the Anatolian Seljuk domed madrasas with its domed courtyard style. Kalavun Madrasah and Maristan (1285) in Cairo, Nasiriyya Madrasah (1303) and Sultan Hasan Madrasah (1362) were continued with a monumental architecture that shaped the layout of the four-iwan courtyard (Cantay, 1991).

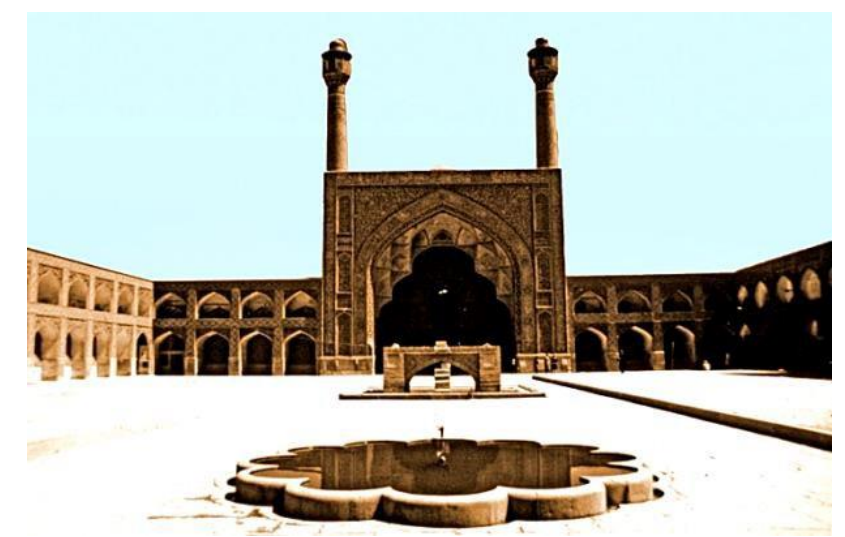

Figure 3. Courtyard of the Isfahan Grand Mosque, which exemplifies the four-iwan courtyard type-Iran (Cantay, 1991).

\section{Courtyards in Anatolian Seljuk State and Anatolian Principalities Architecture}

Anatolian Seljuk architecture, in addition to its own innovations, includes some structures in pre-Anatolian Turkish architecture and this feature covers the whole of the values that the old traditions are kept alive. The courtyard with four iwans and courtyard-iwans-dome establishments related to the architecture of the courtyard came to life in Anatolian Seljuk architecture and became the features that reveal the integrity and continuity of Turkish art. In many Seljuk madrasas such as Kayseri Sahabiye Madrasah (1267-1268), it is seen that fouriwan courtyard style was applied with different sized iwans behind the porticoes. Evdir Han (1214-1219) on the Antalya-Isparta road has the appearance of a structure built in the form of four-iwan courtyard with its porticoes. Malatya Ulu Mosque (1224) is a courtyard-eyvan- 
dome building that connects Anatolian Seljuk architecture to the pre-Anatolian period. Konya Alaeddin Mosque, Sivas and Sinop Ulu mosques are mosques with courtyards. In Kayseri, the Köluk Mosque and Madrasa, and the Hacı Kılıç Mosque and Madrasa, are the combined structures where the mosque and madrasah structures share the same courtyard. The courtyard madrasas of the Anatolian Seljuks with their porched courtyards through stone-decorated gates and the main iwans rising on the structures opposite the entrance are important works in which courtyard architecture is used (Konya Sırçalı Medrese, I-242). In the two-storey courtyard porches of Tokat Gökmedrese (around 1275) (Figure 4), In order to provide sufficient surface to decorate the mosaic tiles, columns at the bottom and rectangular crosssection with large surface feet at the top were used. This different choice between the carrier and the carried object explains the importance given to the tile. Tokat Gökmedrese and Kayseri Çifte Madrasa (1206) are built with two side by side courtyards located on parallel axes with a certain scale. Mardin Sultan Isa Madrasa (1385) is an important monument that uses courtyard architecture with its two large pools in the courtyard filled with water from the iwan with selsebil (Cantay, 1991).

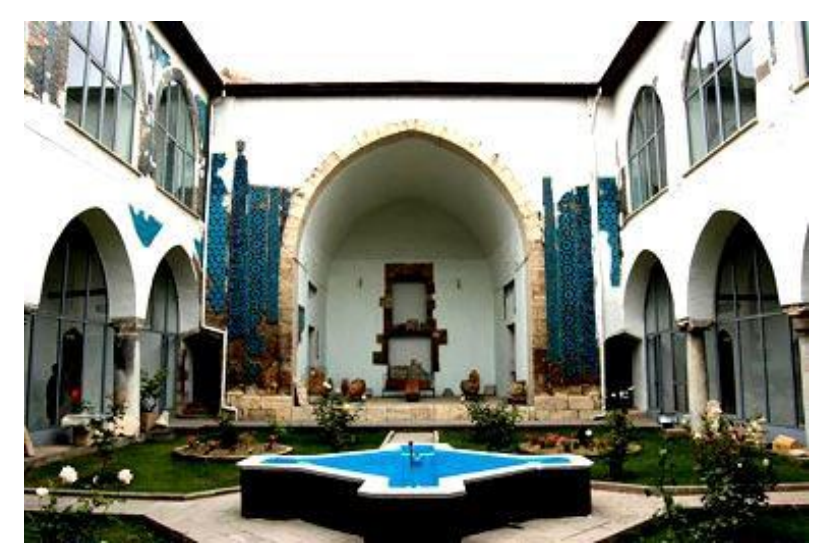

Figure 4. Gokmedrese's courtyard with duplex porches Tokat (http://www.yesilirmakbasinmuseums.org.tr/tokat/tr/mn1.html)

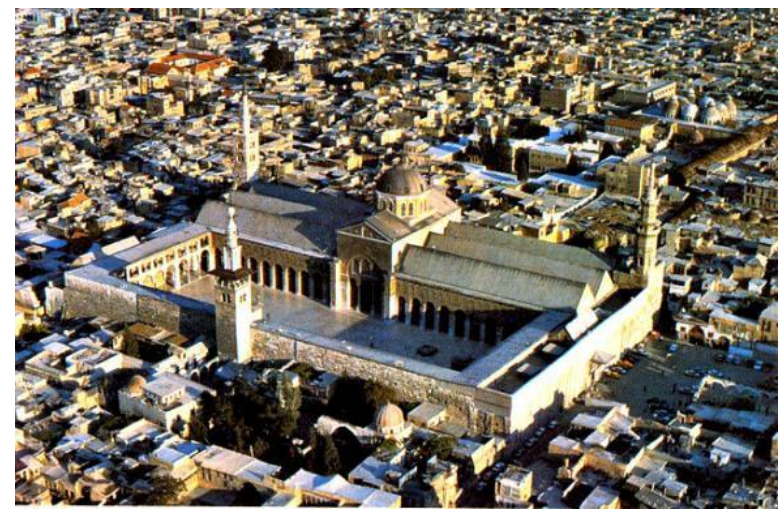

Figure 5 The courtyard of the Damascus Umayyad Mosque with a rectangular rectangular plan-Syria (https://tr.redsearch.org/images/8705526\#images-16) 


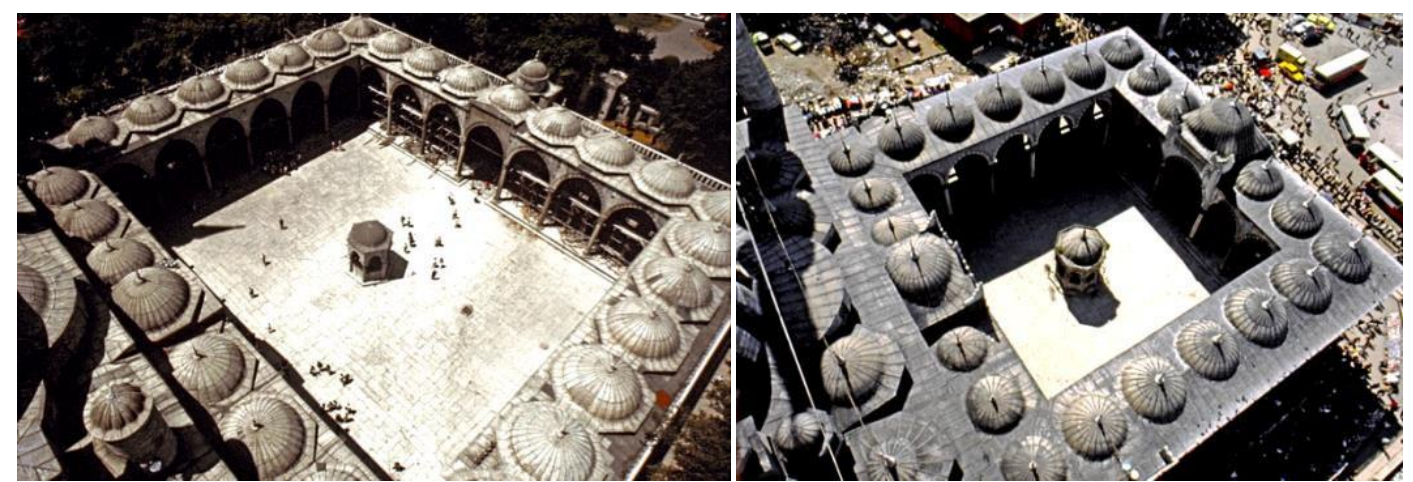

Figure 6 Rectangular-shaped courtyard of Sultan Ahmet Mosque and square-shaped courtyard of Eminönü Newmosque, Istanbul (Cantay, 1991)

\section{Cultural Meaning of the House and Courtyard}

The interior layout of all houses; reflects culture and tradition, technology and wealth as well as beliefs and behaviors (Roberts, 1996:68). One of the factors shaping the house is the cosmogony and worldview of the cultural society that forms it. In this way, cultures imitate the universe and the world they perceive differently as their own style by reconstructing them in a microcosm manner (Rapoport, 1969:50-51). This effect, which is most clearly seen in pre-industrial and primitive societies, has faded or disappeared in modern societies, but it is possible to see some traces of traditional cultures in the past (Xu, 1998:271-282; Hong and et al., 2001:126-127).

In terms of spatial design, traditional Turkish houses consist of two basic units: room and sofa (Eldem, 1955:14). The open spaces in front of the tents in nomadic Turkish culture are the result of cultural adaptation; firstly, it became an open or closed courtyard in front of the house where daily life was carried out and then a sofa (Köse, 2005:181). Although they are spatially, semantically, functionally separated units, the common characteristic is the courtyard and sofas are the outdoor open spaces of the traditional Turkish house.

According to the perceptions of the Turks, the world is not static but mobile; movement is the basic element that shapes the lifestyle (Ögel, 1991:248). On a large scale, the phenomenon of going to different places according to the seasons emerged in nomadic style was applied to the living space on a narrow scale and efforts to achieve a similar environment have resulted in solutions inspired by the culture of migration within the home (Küçükerman, 1991). While the room or house is a place to stay at night and in winter, the courtyard and sofa are shaped as daytime and summer living spaces (Kazmaoğlu ve Tanyeli, 1979:29-41; Ögel, 1991:67-68)

\section{Features of the Courtyard in a Traditioal Turkish House and Natural/Cultural Factors Affecting Courtyard Design}

\section{Natural factors affecting the design of the courtyard in a traditional Turkish house}

Bozkurt and Altınçekiç (2013) explained the natural factors as follows: 
Climate; Increasing climatic diversity of a large region such as Anatolia is an important factor in determining preferences such as spatial arrangement, courtyard formation, roof cover and facade features. The courtyards shaped according to rainfall, temperature, wind and humidity values; high walls provide control of temperature and reduce the effect of wind. Moisture balance in the courtyard is achieved by the use of materials such as stones that hold moisture in areas where moisture is intense, and the use of water surfaces and pools in areas with low humidity. In particular, the vegetative elements used in the courtyard absorb excess moisture and then slowly release it into the atmosphere.

Topography; In all the settlements of Anatolia, the street texture was planned parallel to the slope. In general, elevation differences due to topography are not observed on courtyard floors in Anatolia. In the Safranbolu area, it is possible to see barrier samples created in the courtyard for topographical reasons. Although topography is effective in the development of the housing area and the formation of the urban character, it is not a determining factor in terms of form.

Soil; The quality, depth and permeability of the soil in an area is effective in courtyard formation, but it is not determinative in terms of form as in topography. Usually, soil is used as a building material on courtyard walls, in the construction of adobe and as a plaster material. In addition, the quality and depth of the soil is an important factor for the yield of plants to grow in the courtyard.

Building materials; The material used in the courtyard is similar to the material used in the building. The materials used in residential and courtyard walls are selected according to local conditions; wood material is widely used due to the high density of forest areas in the Black Sea area, while stones and mudbrick are used in Eastern and Central Anatolia. In addition, heat dissipation and retention properties of the material are also utilized. In this way, the temperature of the living spaces is maintained and large temperature diferences are prevented. Plant element; Traditional architecture is a type of building that is compatible with nature and is a product of human ecology. The presence of the courtyard, due to the microclimatic environment they provide, allows to grow warm climate plants in cold regions. In addition, plant elements in the courtyard are the most important natural factors that provide shade effect, wind protection, insulation activities, heat transfer and microclimate. In all the courtyards in Anatolia, vegetative elements were included, flowering plants and fruit trees were frequently preferred, fruit trees were used to create a shadow effect in accordance with the climatic conditions of the region, and of course their fruits were utilized. They were not bound to a certain criterion for vegetative arrangement in the regions, but they were planted in places left empty on the courtyard floorings.

\section{Cultural factors affecting courtyard design in traditional Turkish house}

Since the nomadic culture, the place of living has been interactive and integrated with nature; the most spacious, open and comfortable place of the house is chosen as the living space; the dark, damp, distant and airless places in the house were used as less used areas or areas like stables and toilets that were preferred to be behind (Küçükerman, 1991:55). In this respect, the courtyard is one of the most suitable places of daily life in the traditional Turkish house. However, the phenomenon of "displacement" and "variability" (the use of the same environment for other purposes during the day) from the traditional nomadic culture; portable household items such as folding tables, different materials for above ground usage, cushions, folding beds supported the use of the courtyard as a living space (Küçükerman, 1991:80-81). 
Many different solutions have been created in the established culture due to environmental adaptations, and although the basic needs have been moved into the house today, the courtyard was preferred for cooking and sometimes eating in the traditional Turkish house. In the Turkey's most traditional village house, the oven, tandoori or cafeteria is separate from the house and is a separate section within the courtyard. The wall stove is a cooking place, often set up in a corner of the hall. Meals are eaten in the hall in nice weather. With this arrangement, the interior of the house is protected from smoke and odor. The basic needs of resting, sitting and sleeping activities are also important factors shaping the house and courtyard.

The courtyards are not primarily for defense needs in the traditional Turkish house, but are also areas to meet this need. Since the courtyards are surrounded by walls or fences, they limit the entrance of foreigners and create a buffer zone for the defense of the house. Courtyards are also the place of production of food, perhaps which is the most basic need of human beings (Nevter and Beser, 2003:6; Tunçdilek, 1967:78-90; Altaş ve diğ., 2006:74) and courtyards can turn into an animal shelter even when the livestock economy is dominant (Yürüdür, 2006:259). In traditional Turkish houses, in addition to being functional in terms of meeting some basic needs, the courtyard is a general and useful place where traditional Turkish family comes together, is used as a common area, and daily works are carried out.

Among other cultural factors, the status of women and privacy plays a decisive role in shaping the traditional Turkish house (Küçükerman, 1991:51). In general, the courtyard is of particular importance to the woman. Even though the courtyard is the courtyard is the entrance to the house from the outside and the "semi-private place" (Asatekin, 1994: 79) where firstly foreigners pass through it, it is also the woman's window to nature, who is identified with the house. Because of the privacy of family life, constructed as inward-facing courtyards (Kuban, 1982: 197-198) are large spaces that are part of social life and where traditional Turkish women are opened to nature, where most of their daily work is carried out, rested and entertained the guests (Bozkurt and Altınçekiç, 2013).

\section{The IMpact of Modernism on Urban Courtyards}

With modernism, the separation of buildings and activities in the city reduces the chances of people to have close relationships. Cities have become places with great distances between people, functions and events. Automobile-based transportation can have negative effects on outdoor life (Gehl, 1987).

In the Republic Period (1923 and beyond); after 1927, social life and cultural changes were reflected in architecture. It is seen that foreign architects played an effective role in the formation of the city in this period. For example, facade decorations were simplified and tended to different cultures. Before 1950, The construction of the city in Turkey covers the processes that can be described as "restructuring" and "outward openness". In this context, while all kinds of social infrastructure and technical studies are carried out, the general planning of the cities has been shaped by the city plans of the architects coming from abroad. For example; The French Danger Brothers designed each other symmetrically crossing streets and symmetrical squares with the influence of the 'Beautiful City' trend for Izmir, which continue to be influential today and who also included the Cultural Park in this context. (Tanyeli, 1992; Demirel, 2009). 
After the 1950s, the traditional and regional conception of architecture was left aside and western-style constructions gained importance. It is a period in which the shanty housing has begun as well as important developments in urban designs. During this period, traditional buildings and open space were almost abandoned with the establishment of multiple housing and apartment buildings (Bozkurt ve Altınçekiç, 2013). In addition, the speed of industrialization has increased and the urban road transport has improved. Along with the practical urban trend, aesthetic concerns have been ignored in cities where rapid development has taken place. An addressing objective problems approach such as housing. was followed (Tanyeli, 1992; Demirel, 2009).

In summary, in the modern period, outdoor spaces with the urban courtyard feature are not seen as before, but areas between high building masses (Figure 7) are planned and used as urban courtyards.
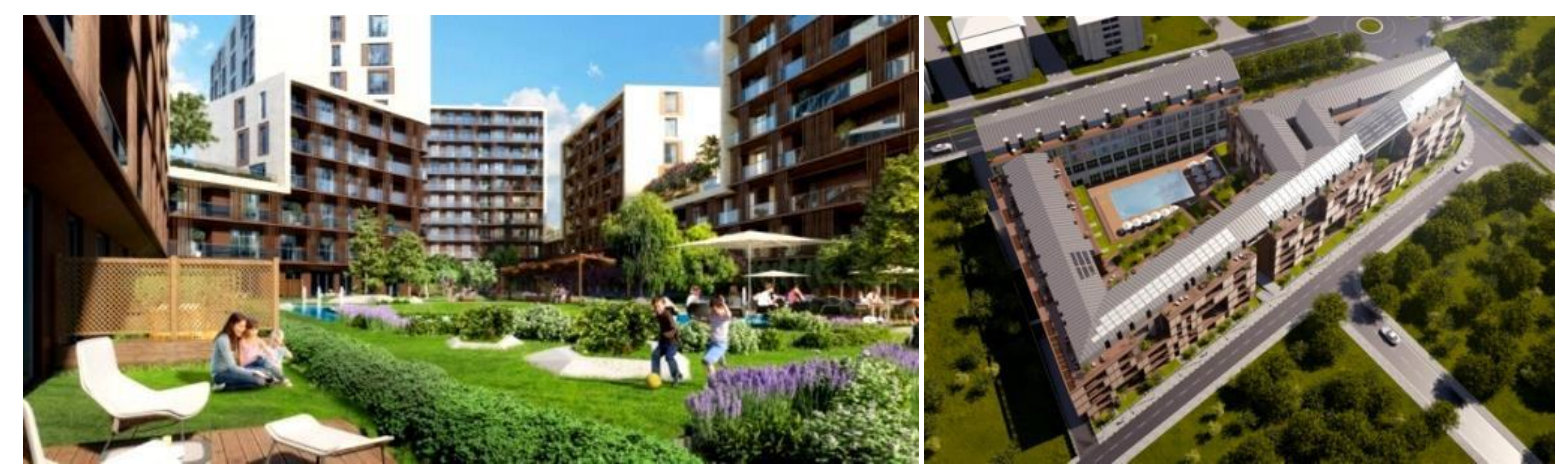

Figure 7.Examples of modern period courtyard housing (Anonymous-a)

\section{CONCLUSION}

Courtyard houses are an inseparable part of the urban structure and housing forms, they are the basic unit of traditional architecture in the historical process, do not have a certain style but change in time according to various factors and are shaped by interaction with the cultures in the geography where they are located. The courtyards are the social interaction places of the family in Anatolian Turkish houses. They are also areas for rest, cooking, eating, storage, agricultural production and protection. Traditional rural Turkish houses are located in the courtyard. The courtyard is at the front of the house, firstly entrance is done from the street to the courtyard then to the house. It is in the position of transition between private place (house) and general place (street). Although the entrance of the foreigners is limited and controlled, it is a semi-private place of the house because it is accessible from outside and open to sight.

The courtyards as a heritage of nomadic Turkish culture have been the most important living place of the house. The desire to live interactive and integrated with nature inherited from nomadic Turkish culture has found a solution in the house through the courtyard. The open green spaces in the courtyard houses are designed as an interior space and isolated from the external environment, a social space is created. Since solidarity and domestic relations are tight in the traditions of Turkish society, the traditional courtyard is the area of social interaction among large families. The large tree shade or hall element in the courtyard are functional places where family members come together, sit and rest, prepare meals and eat. 
Courtyards are also pleasant places where social relations are established with neighbors and even guests are entertained.

As a result of the cultural background of Turkish society which is acquired in the geography where it lives, religious influences and local environmental conditions, Anatolian Turkish household and courtyard developed as an original understanding and interpretation of space have changed due to rapidly developing and changing living conditions. Some of the other changes can be summarized as follows:

- The impact of the population growth, abandonment of crowded family life, opening of the regions to tourism, the effects of differentiation in the understanding of privacy on the understanding of the courtyard

- The functions such as cooking and eating in traditional courtyards have shifted from courtyards to the kitchen of the house,

- The fact that the courtyards are not an agricultural production and storage place where vegetables and fruits are grown, animals are sheltered and products are stored, they become places where recreation anxiety is kept in the foreground.

- City Courtyards contain historical and symbolic meanings as in Roman period In the works of Islamic and Ottoman periods, the areas are only symbolically handled with the construction techniques developed in the modern era, historical meanings were tried to be created by emulating old works in the post-1950 period. In this respect, it can be concluded that some works are similar to other periods in the semantic direction and some works have different meanings in parallel with the changing culture and the world.

Cultural factors are the main determining factors in the formation of courtyards. As a legacy of traditional nomadic Turkish culture, most of the basic needs such as bright environment, fresh air, cooking and eating and resting were met in the courtyard and they have also become very meaningful, functional, pleasant and indispensable places for traditional Turkish society in terms of agricultural production, storage and protection functions.

Traditional Turkish house courtyards, shaped according to world view and lifestyle, are in the process of rapid change and deterioration due to the current globalization and popular culture invasion. While the change in rural areas, which are close to the cities of popular culture and where relations with the city are intense, change is more distorting and faster, traditional courtyard layout and understanding can be better preserved in remote rural areas where relations with the city are weaker. The perception of privacy has changed due to crowding, the use of the courtyard for seating purposes has decreased, the position of the seating has changed and shifted to the hall in front of the house or balcony. The portable seating tools used in the traditional courtyard have been replaced by factory-built fixed items.

In general, the courtyards are considered as elements that provide comfortable living opportunities in different climates and topography with different forms and positions, they are seen as places that can cope with hot climates alone, whether on housing scale or settlement scale. Providing the opportunity to live in both indoor and outdoor areas with the microclimate effect and doing all of this by taking advantage of natural factors will ensure that it remains the subject of today's landscape architecture and architecture disciplines. As a result of all this information, the courtyards will always remain modern and up to date. 


\section{REFERENCES}

Altas, N. et al., 2006. Domaniç'te Kır Meskenleri (Rural residences in Domanic). Doğu Coğrafya Dergisi (Journal of Eastern Geography), no. 16:74. Erzurum.

Anonymous-a.http://www.msxlabs.org/forum/x-sozluk/87503-avlu-avlu-nedir-avluhakkinda.html (accessed: May 12, 2012).

Arseven, C. E., 1975. Sanat Ansiklopedisi (Art Encyclopedia), Vol I. MEB Yayınevi (MEB Publication), p:131. Istanbul.

Asatekin, G., 1994. Anadolu'daki Geleneksel Konut Mimarisinin Biçimlenmesinde AileKonut Karşılıklı İlişkilerinin Rolü. Kent Planlama, Politik, Sanat. Tarık Okyay Anısına Yazilar (The Role of Family-House Mutual Relations in the Formation of Traditional Housing Architecture in Anatolia. Urban Planning, Political, Art. Articles in Memory of Tarık Okyay). ODTÜ Mimarlık Fakültesi Yayını (METU Faculty of Architecture Publication), Ankara. p:79.

Bozkurt, S. G. and Altınçekiç, H., 2013. Anadolu'da Geleneksel Konut ve Avluların Özellikleri ile Tarihsel Gelişiminin Safranbolu Evleri Örneğinde İrdelenmesi (Characteristics of Traditional Houses and Courtyards in Anatolia and Exploring its Historical Development in the Case of Safranbolu Houses). İstanbul Üniversitesi Orman Fakültesi Dergisi (Journal of Istanbul University Faculty of Forestry), no. 63(1): 69-91.

Cantay, T., 1991. Avlu (Courtyard), TDV İslam Ansiklopedisi (TDV Islamic Encyclopedia), Vol: 4, Istanbul.

Demirel, Ö., 2009. Ülke Mekansal Planlaması İçinde Ekolojik Ağırlıklı Disiplin Olma Yönünde Bir Misyon Taşıyan Peyzaj Mimarlı̆̆ı Mesleğinin Yeri (The Place of Landscape Architecture Profession with a Mission of Ecological Weighted Discipline in Country Spatial Planning). Peyzaj Mimarlığı Akademik İşbirliği Toplantısı (Landscape Architecture Academic Cooperation Meeting), Süleyman Demirel Üniversitesi (Suleyman Demirel Univesity), Isparta.

Eldem, S. H., 1955. Türk Evi Plan Tipleri (Turkish House Plan Types). İstanbul Teknik Üniversitesi Mimarlık Fakültesi Yayınları (Istanbul Technical University Architecture Faculty Publication), Istanbul.

Gehl, J., 1987. Life between buildings: Using public space, New York, Van Nostrand Reinhold, p.202.

Günay, B. ve Selman, B., 1994. Kentsel Görüntü ve Kentsel Estetik Örnek Kent: Ankara (Urban Image and Urban Aesthetics Sample City: Ankara), Editor İ. Tekeli, Kent, Planlama, Politika, Sanat (City, Planning, Politics, Art), ODTÜ Mimarlık Fakültesi Yayını (METU Faculty of Architecture Publication), 277-319, Ankara.

Hong, Hyung-Ock and et al, 2001. A Study of the Ecological Perspectives in Traditional Korean Homes. Journal of Korean Home Economics Association English Edition: Vol 2, No. 1, December 2001.www.khea.or.kr/InternationalJournal/2001/8.PDF, (accessed: Feb 20, 12, 2006).

Kazmaoğlu, M. ve Tanyeli, U., 1979. Anadolu Konut Mimarisinde Bölgesel Farklılıklar (Regional Differences in Anatolian Housing Architecture). Yap1 (Structure): 33, 1979/13, s.29-41. Istanbul.

Köse, A., 2005. “Türkiye'de Geleneksel Kırsal Konut Planlarında Göçebe Türk Kültürü İzleri (Traces of the Nomadic Turkish Culture at Traditional Rural Housing Plan in Turkey)." Afyon Kocatepe Üniv. Sosyal Bilimler Dergisi (Afyon Kocatepe University Journal of Social Sciences VII, no:2: 165-200, Aralık 2005. Afyonkarahisar. 
Köse, A., 2007. "Balıkesir Çevresinde Geleneksel Kırsal Avlu Peyzajı ve Değiş̧imi (Traditional Rural Courtyard Landscape and Change Around Balıkesir)." Doğu Coğrafya Dergisi (Journal of Eastern Geography), no. 12/18.

Kuban, D., 1982. Türk Ev Geleneği Üzerine Gözlemler. Türk ve İslam Sanatı Üzerine Denemeler (Observations on Turkish Home Tradition. Essays on Turkish and Islamic Art), Arkeoloji ve Sanat Yayınları (Archeology and Art Publications). p: 197-198. İstanbul.

Küçükerman, Ö., 1991. Kendi Mekanının Arayışı İçinde Türk Evi (Turkish House in Search of ts Own Place). Türkiye Turing ve Otomobil Kurumu (Touring and Automobile Club of Turkey), s.87-91. İstanbul.

Meydan Larousse, 1990. Cilt 1,4 Meydan Gazetecilik ve Neşriyat Ltd.Şti (Meydan Journalism and Publication Co.Ltd). p:441-886. İstanbul. Nevter, Z. and Beser, O., 2003.

Sustainability of Gren Network and Built Environment Relation: Case Study: Lefke. SBE ${ }^{e e} 03$ Technology and Management for Sustainable Building CSIR, 26-30 May 2003, s:6. Accessed:March 24, 2012. www.sustainablesettlement.co.za/event/SBE2003/Proceedings/Nevter_Zafer.pdf

Ögel, B., 1991. Türk Kültür Tarihine Giriş. III (Introduction to Turkish Cultural History III). Kültür Bakanlığı (Ministry of Culture)/638, Kültür Eserleri (Cultural Works )/46, Ankara.

Şimşek, O., 2015. "Büyük Selçuklu Mimarisinde Avlu Kimliği (Courtyard Identity in Great Seljuk Architecture)." Fatih Sultan Mehmet Vakıf Üniversitesi, İnsan ve Toplum Bilimleri Dergisi (Fatih Sultan Mehmet Foundation University, Journal of Humanities and Social Sciences), no. 5.

Rapoport, A., 1969. House Form and Culture. Prentice-Hall, Inc, London.

Roberts, B. K., 1996. Landscapes of Settlement, prehistory to the present. Routledge, London and New York.

Tanyeli, U., 1992. "Çağdaş İzmir'in Mimarlık Serüveni/ Üç İzmir (Architecture Adventure of Contemporary Izmir/ Three Izmir)", Yapı Kredi Yayınları (Yapı Kredi Publications), Istanbul, p.327-340.

Tunçdilek, N., 1967. "Türkiye İskan Coğrafyası, Kır İskanı (Köy-Altı İskan Şekilleri) (Turkey Settlement Geography, Rural Settlement (Sub-Village Settlement Figure)).” İstanbul Üniversitesi Edebiyat Fakültesi Yayını (Istanbul University Faculty of Letters Publication) no. 1283, Coğrafya Enstitüsü Yayını (Geography Institute Publication) no. 49: 78-90. Istanbul.

Yürüdür, E., 2006. "Yakın Mesafeli Yaylacılık Faaliyetlerine Bir Örnek: Tokat Yaylacık Dağında Yaylacılık (An Example of Close-Range Transhumance Activities: Transhumance Activities at Yaylacik Mountain of Tokat).” Doğu Coğrafya Dergisi (Journal of Eastern Geography) no. 16: 259. Erzurum.

Xu, P., 1998. Feng-Shui Models Structured Traditional Beijing Courdyard Houses. Journal Architectural Planning Research, 15:4 (Winter, 1998), 271- 282, Locke Science Publishing, Inc. Chicago. 25.02.2006 www.japr.homestead.com/files/Xu.pdf . 